\title{
THE EFFECTS OF LIPOTROPIC FACTORS ON PHOSPHOLIPIDE TURNOVER IN THE PLASMA OF PATIENTS WITH CIRRHOSIS OF THE LIVER, AS INDICATED BY RADIOACTIVE PHOSPHORUS ${ }^{1}$
}

\author{
BY W. E. CORNATZER AND DAVID CAYER \\ (From the Departments of Biochemistry and Internal Medicine, The Bowman Gray School of \\ Medicine of Wake Forest College and The North Carolina Baptist Hospital, \\ Winston-Salem, N. C.)
}

(Submitted for publication August 11, 1949; accepted, January 9, 1950)

Fatty infiltration of the liver may be produced experimentally in animals by various means, including dietary restriction of proteins, of choline or choline precursors, or of vitamins, as well as the use of hepatotoxins (1). The lesions produced may progress to a pathologic picture resembling that of cirrhosis in human beings. Although it is not universally agreed that the pathogenesis of human cirrhosis is similar to that in animals, many investigators have felt that fatty infiltration represents an intermediate phase, which, while reversible, may also progress to cirrhosis.

It has been noted in experimental animals that methionine and choline have a lipotropic action, preventing the deposition of fat in the liver as well as enhancing its removal (2). This effect is thought to result from an increase in the formation and the turnover of phospholipides (3). Indeed, in experimental animals with fatty infiltration of the liver induced by diet, it has been shown by the use of radiophosphorus that choline or methionine will cause an increase in the phospholipide turnover in the liver $(4,5)$.

In human beings the therapeutic value of choline and methionine in the treatment of certain forms of chronic hepatitis, with or without the presence of fatty infiltration of the liver, is open to question (6). Numerous observers have noted a reduction in liver size and both clinical and laboratory evidence of improvement which they felt could be attributed directly to the use of choline or

1 This investigation was supported (in part) by a research grant from the Division of Research Grants and Fellowships of the National Institutes of Health, U. S. Public Health Service. The $\mathrm{P}^{2}$ used in these experiments was obtained from the National Laboratories, Oak Ridge, Tennessee, on allocation from the United States Atomic Energy Commission. methionine (7). Others have been unwilling to ascribe any specific benefit to these substances (8).

Since the phospholipide turnover in the liver is probably reflected by the amounts of newly formed phospholipides in the plasma, the use of radioactive phosphorus appears to offer for the first time an objective method of evaluating the effects of the lipotropic agents in the treatment of certain forms of liver diseases. We have reported previously on the validity of the technical method, and have calculated the radioactivity and the specific activity of the plasma lipides in a few persons with liver disease (9). In two of these patients the effects of a single large dose of choline chloride or methionine (dl) $(10 \mathrm{Gm}$.) were studied, and an apparent deficiency of lipotropic substances was demonstrated in human beings for the first time. This study has been extended to include a larger series of patients (10).

The preceding paper reported a study of normal phospholipide turnover in well persons on an average adequate diet. This study demonstrated the failure of a large single dose of choline or methionine to affect the turnover in normal individuals.

\section{METHOD AND PLAN OF STUDY}

The methods and plan of study were similar to those previously described for normal individuals (10). Determinations have been made on the inorganic fraction of the plasma so that the isotopic concentration in the lipide fraction can be expressed as a function of the specific activity of the inorganic phosphorus ("relative specific activity").

A total of 20 patients- 16 men and four women-, all having clinical and laboratory evidence of portal cirrhosis, were studied.

The experiments were carried out in an attempt to answer the following questions: Was there any demonstrable change in the phospholipide turnover following 
therapy when the patients were clinically improved? Did the administration of a large single dose of choline or methionine $(10 \mathrm{Gm}$.) have any demonstrable effect on the phospholipide turnover before treatment and when the condition was acute? Was the effect of the large dose, if present, persistent after treatment and clinical improvement?

Repeated experiments with the injection of radioactive phosphorus were made in the same individuals before and after treatment with lipotropic agents. In several of these patients, treated and untreated, the effect of a single large dose ("test dose") of lipotropic material was also studied, and the results were compared with those obtained in normal persons (10).

Since it was noted previously that the plasma phospholipide phosphorus varies widely between normal individuals, but is relatively constant over a period of months in the same individual, each patient was used as his own control and was restudied, when possible, at two-month intervals.

The treatment given during this study included a 3,500 calorie diet, containing 120 to $140 \mathrm{Gm}$. of protein, 130 to $150 \mathrm{Gm}$. of fat, and 350 to $400 \mathrm{Gm}$. of carbohydrate.
When edema and ascites were present, the salt intake was restricted, but water was allowed $a b$ libitum. After preliminary diagnostic study, all patients received maintenance doses of synthetic $B$ complex vitamins and $3 \mathrm{Gm}$. of methionine or choline chloride (or its equivalent as choline dihydrogen citrate) per day. Five hundred to 1,000 cc. of 5 per cent dextrose in distilled water were administered intravenously each day. One cc. of crude liver extract was given intramuscularly three times weekly. Plasma and blood were not used. Paracentesis was done only if diuretics failed to give relief, or when the accumulation of fluid produced respiratory difficulty or inability to eat.

Laboratory studies were performed at monthly intervals to estimate the response to treatment. These included urinalysis and the following routine studies of the blood: determinations of the hemoglobin content, red and white blood cell counts and differential counts; bromsulfalein, hippuric acid, and galactose tolerance tests; and determinations of the icterus index, prothrombin time, total serum proteins, and albumin and globulin fractions. Serial aspiration biopsies of the liver were also performed.

TABLE I

Phospholipide turnover before and after treatment in patients with chronic hepatitis (Group 1)

(See TABLE I-Continued, next page)

\begin{tabular}{|c|c|c|c|c|c|c|c|c|c|c|c|c|c|}
\hline \multirow{3}{*}{ Name, age, sex } & \multirow{3}{*}{$\begin{array}{c}\text { Time of } \\
\text { injec- } \\
\text { tion of } \\
\text { Pas* }\end{array}$} & \multirow{3}{*}{$\begin{array}{c}0 \text { hour } \\
\begin{array}{c}\text { Phos- } \\
\text { phorus } \\
\text { mg./ } \\
100 \mathrm{cc} .\end{array} \\
\text { Lipide }\end{array}$} & \multicolumn{7}{|c|}{24 hours } & \multicolumn{4}{|c|}{48 hours } \\
\hline & & & \multicolumn{2}{|c|}{$\begin{array}{l}\text { Phosphorus } \\
\text { mg./100 cc. }\end{array}$} & \multicolumn{2}{|c|}{$\begin{array}{l}\text { Radioactivity† } \\
\text { r.r.u./100 cc. }\end{array}$} & \multicolumn{2}{|c|}{$\begin{array}{c}\text { Specific activity } \neq \\
\times 100\end{array}$} & \multirow{2}{*}{$\begin{array}{r}\begin{array}{r}\text { Relative } \\
\text { specific } \\
\text { activity } \\
\times 100\end{array} \\
\text { Lipide }\end{array}$} & \multicolumn{2}{|c|}{$\begin{array}{l}\text { Phosphorus } \\
m g . / 100 \text { cc. }\end{array}$} & \multicolumn{2}{|c|}{$\begin{array}{l}\text { Radioactivity† } \\
\text { r.r.u./100 cc. }\end{array}$} \\
\hline & & & Inorg. & Lipide & Inorg. & Lipide & Inorg. & Lipide & & Inorg. & Lipide & Inorg. & Lipide \\
\hline \multirow[t]{3}{*}{ R. C. C. $44 \mathrm{M}$} & 1 & 6.92 & 2.73 & 7.75 & .848 & .890 & 31.0 & 11.5 & 37.0 & & & & \\
\hline & 2 & 8.33 & 3.03 & 7.64 & .833 & .846 & 27.5 & 11.0 & 40.3 & & & & \\
\hline & 3 & 9.13 & 2.44 & 7.01 & .696 & .683 & 28.5 & 9.7 & 33.0 & & & & \\
\hline \multirow[t]{2}{*}{ A. K. O. $50 \mathrm{M}$} & 1 & 5.53 & & 5.83 & & .506 & & 8.7 & & & & & \\
\hline & 2 & 4.68 & 4.10 & 7.68 & 1.182 & 1.085 & 28.9 & 14.1 & 49.0 & & & & \\
\hline \multirow[t]{3}{*}{ W. R.S. 49 M } & 1 & 10.59 & & 11.65 & & 1.015 & & 8.7 & & & & & \\
\hline & 2 & 7.55 & 3.90 & 9.20 & 1.750 & 1.030 & 44.9 & 11.2 & 24.9 & & & & \\
\hline & $3 \|$ & 8.75 & 3.46 & 9.08 & 1.200 & .804 & 34.7 & 8.8 & 25.3 & 2.87 & 9.34 & .692 & .952 \\
\hline \multirow[t]{3}{*}{ R. N. O. $43 \mathrm{M}$} & 1 & 5.43 & & 5.54 & & .450 & & 8.1 & & & & & \\
\hline & 2 & 8.21 & 3.44 & 7.80 & 1.381 & .756 & 40.2 & 9.7 & 24.1 & & & & \\
\hline & $3 \|$ & 7.83 & 3.51 & 7.28 & .536 & .593 & 15.3 & 8.2 & 53.3 & 3.13 & 7.55 & .415 & .898 \\
\hline \multirow[t]{2}{*}{$\begin{array}{lll}\text { E. S. } & 53 \mathrm{M}\end{array}$} & 1 & 14.03 & 2.74 & 16.22 & .833 & 2.259 & 30.4 & 13.9 & 45.7 & 2.82 & 12.49 & .776 & 3.526 \\
\hline & $2 \|$ & 26.50 & 3.13 & 23.40 & 1.201 & 3.593 & 38.4 & 15.4 & 40.1 & 2.76 & 24.40 & .728 & 4.571 \\
\hline A. H. D. $60 \mathrm{M}$ & 2 & 6.84 & 3.07 & 7.45 & 1.278 & .458 & 41.6 & 6.2 & 14.9 & 3.05 & 6.63 & .612 & .692 \\
\hline I. L. M. 46 F & 2 & 6.70 & & 5.89 & & .817 & & 13.8 & & 3.23 & 6.76 & .715 & 1.219 \\
\hline W. H. $\quad 54$ M & $2 \|$ & 7.24 & 2.83 & 6.21 & 1.086 & .278 & 38.3 & 4.5 & 11.7 & 2.49 & 6.40 & .560 & .721 \\
\hline
\end{tabular}

-1-Before treatment.

2-After two months of treatment with methionine $(3 \mathrm{Gm} . /$ day $)$.

3 -After four months of treatment with methionine (3 Gm./day).

† Expressed in relative radioactive units (r.r.u.), the total dose injected being equal to $10^{4}$ r.r.u. (This is identical to the per cent of the dose of $P^{2}$ injected $\times 100$ found in the phospholipides.) 
TABLE I-Continued

Phospholipide turnover before and after treatment in patients with chronic hepatitis (Group 1)

\begin{tabular}{|c|c|c|c|c|c|c|c|c|c|c|c|c|c|}
\hline \multirow{3}{*}{ Patient } & \multirow{3}{*}{$\begin{array}{c}\text { Time of } \\
\text { injec- } \\
\text { tion of } \\
\text { pas }\end{array}$} & \multicolumn{3}{|c|}{48 hours } & \multicolumn{7}{|c|}{ 72-96 hours } & \multirow{3}{*}{$\begin{array}{c}\begin{array}{c}\text { Specific } \\
\text { activity } \\
\text { of urine } \\
\text { inorganic } \\
\text { phosphorus }\end{array} \\
21-24 \mathrm{hr} \text {. }\end{array}$} & \multirow{3}{*}{$\begin{array}{c}\begin{array}{c}\text { Ratio of } \\
\text { specific } \\
\text { activities } \\
\text { of } \frac{\text { urine P }}{\text { plasma P }}\end{array} \\
\frac{21-24 \mathrm{hr} .}{24 \mathrm{hr} .}\end{array}$} \\
\hline & & \multicolumn{2}{|c|}{$\begin{array}{c}\text { Specific } \\
\text { activity } \\
\times 100\end{array}$} & \multirow{2}{*}{$\begin{array}{c}\begin{array}{c}\text { Relative } \\
\text { opecific } \\
\text { activity } 8 \\
\times 100\end{array} \\
\text { Lipide }\end{array}$} & \multicolumn{2}{|c|}{$\begin{array}{l}\text { Phosphorus } \\
\text { mg./100 cc. }\end{array}$} & \multicolumn{2}{|c|}{$\begin{array}{l}\text { Radioactivityt } \\
\text { r.r.u./100 cc. }\end{array}$} & \multicolumn{2}{|c|}{$\begin{array}{c}\text { Specific } \\
\text { activity } \$ \\
\times 100\end{array}$} & \multirow{2}{*}{$\begin{array}{c}\begin{array}{c}\text { Relative } \\
\text { specific } \\
\text { activity } \\
\times 100\end{array} \\
\text { Lipide }\end{array}$} & & \\
\hline & & Inorg. & Lipide & & Inorg. & Lipide & Inorg. & Lipide & Inorg. & Lipide & & & \\
\hline \multirow[t]{3}{*}{ R. C. C. $44 \mathrm{M}$} & 1 & & & & & & & & & & & 39.8 & 1.29 \\
\hline & 2 & & & & & & & & & & & 26.6 & 0.97 \\
\hline & 3 & & & & & & & & & & & & \\
\hline \multirow[t]{2}{*}{ A. K. O. $50 \mathrm{M}$} & 1 & & & & & & & & & & & & \\
\hline & 2 & & & & & & & & & & & 37.7 & 1.30 \\
\hline \multirow[t]{3}{*}{ W. R. S. 49 M } & 1 & & & & & & & & & & & & \\
\hline & 2 & & & & & & & & & & & 50.0 & 1.12 \\
\hline & 3\| & 24.1 & 10.2 & 42.3 & 2.66 & 5.71 & .482 & .688 & 18.0 & 12.0 & 66.7 & 38.9 & 1.12 \\
\hline \multirow[t]{3}{*}{ R. N. O. $43 \mathrm{M}$} & 1 & & & & & & & & & & & & \\
\hline & 2 & & & & & & & & & & & & \\
\hline & $3 \|$ & 13.3 & 11.9 & 89.5 & & & & & & & & 24.5 & 1.60 \\
\hline \multirow[t]{2}{*}{ E. S. $\quad 53 \mathrm{M}$} & 1 & 27.5 & 28.2 & 102.3 & 3.22 & 15.27 & .651 & 3.814 & 20.2 & 24.9 & 123.2 & 51.2 & 1.69 \\
\hline & $2 \|$ & 26.4 & 18.7 & 70.8 & 2.82 & 23.06 & .388 & 4.687 & 13.7 & 20.3 & 148.0 & 47.5 & 1.24 \\
\hline A. H. D. $60 \mathrm{M}$ & 2 & 20.0 & 10.5 & & & & & & & & & 48.7 & 1.18 \\
\hline I. L. M. 46 F & 2 & 22.1 & 18.0 & 81.3 & 3.48 & 3.13 & .423 & .449 & 12.2 & 14.3 & 117.2 & 41.3 & \\
\hline W. H. 54 M & $2 \|$ & 22.5 & 11.2 & 49.7 & 2.61 & 6.26 & .330 & .756 & 12.6 & 12.1 & 96.0 & & \\
\hline
\end{tabular}

$\mp$ Specific activity is the ratio of the radioactivity (in r.r.u.) to the phosphorus (in mg.) in the extracts.

Relative specific activity of plasma phospholipides is the ratio of the specific activity of the phospholipides to the inorganic phosphate.

|| Single large dose of lipotropic agent (choline or methionine) given with the injection of $\mathrm{P}^{*}$.

\section{MATERIAL}

\section{Group 1: Phospholipide turnover measured before and after treatment (Table I and Figure 1)}

Eight patients were studied in this group. There were seven men and one woman, ranging in age from 43 to 60 years, with an average age of 49 years. Seven of the eight patients gave a history of alcoholism. Six had ascites; five had large livers; three were jaundiced. All were considered moderately to severely ill. Biopsies were done before treatment in three instances.

In five patients the phospholipide turnover following an injection of radioactive phosphorus was studied before and after a two-month interval of treatment. Three additional patients, on whom no studies were done before treatment, were studied after a two-month period of treatment.

Three patients were studied a third time after a second two-month period of therapy. This time two patients received a "test dose" of choline simultaneously with the injection of radiophosphorus.
PMOSPHOLIPIDE TURNOVER BEFORE AND AFTER TREATMENT

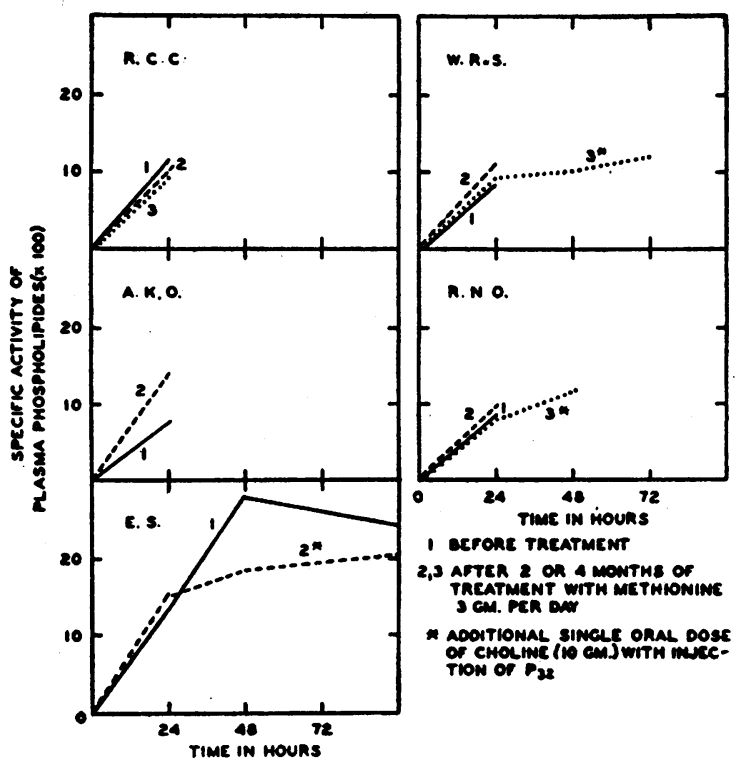

Fic. 1. 
PHOSPHOLIPIOE TURNOVER BEFORE AND DURING TREATMENT AFTER AN INITIAL LARGE DOSE OF LIPOTROPIC ACENTS

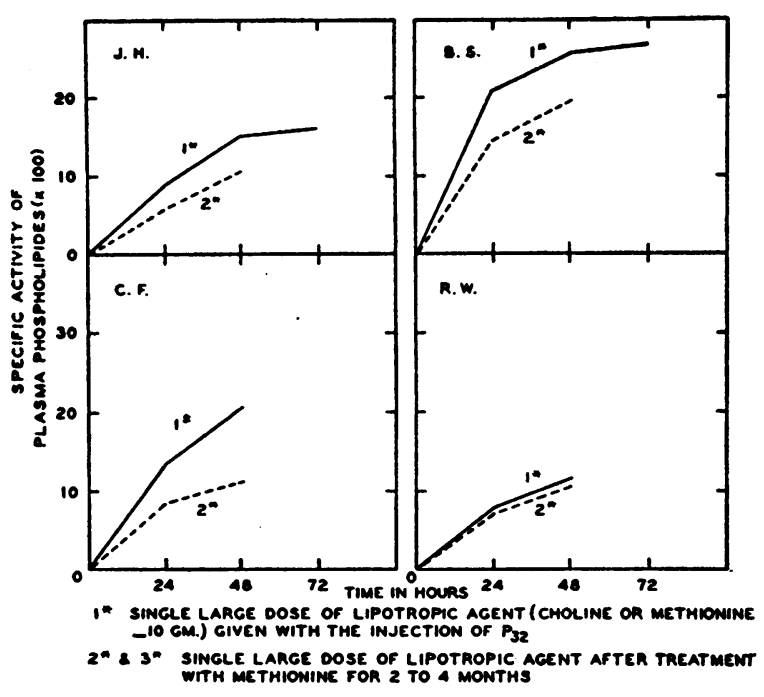

PHOSPHOLIPIDE TURNOVER BEFORE AND DURING TREATMENT AFTER AN INITIAL LARCE DOSE OF LIPOTROPIC AGENT

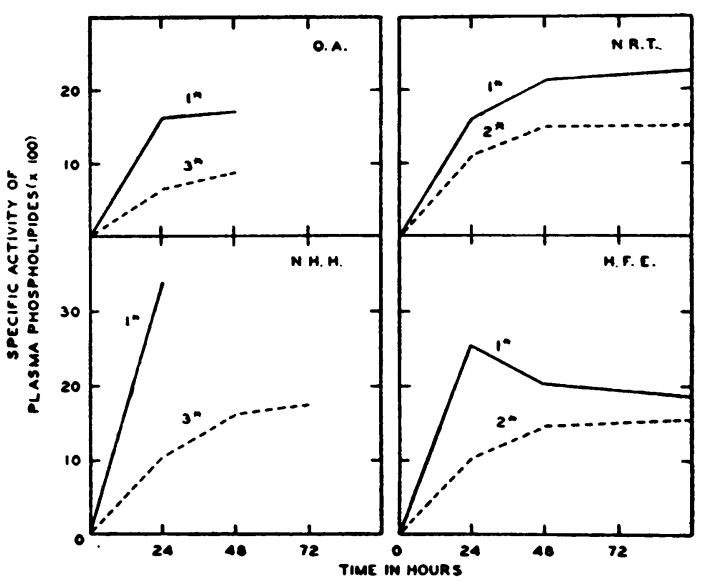

1" SINGLE LARGE DOSE OF LIPOTROPIC AGENT (CMOLINE ON METHIONINE - 10 GMS.) GIVEN WITH THE INJECTION OF $P_{32}$

2" On 30 SINGLE LARGE DOSE OF LIPOTROPIC AGENT AFTER TREATMENT WITH METHIONINE FOR 2 TO 4 MONTHS

FIG. 2.

TABLE II

Phospholipide turnover before and after treatment with a single dose of a lipotropic agent in patients with chronic hepatitis (Group 2)

(See TABLE II-Continued, next page)

\begin{tabular}{|c|c|c|c|c|c|c|c|c|c|c|c|c|c|c|}
\hline Patient & \multirow{3}{*}{$\begin{array}{l}\text { Time } \\
\text { of in- } \\
\text { jection } \\
\text { of pa* }\end{array}$} & \multirow{3}{*}{$\underset{\text { Material }}{\text { given }}$} & \multirow{3}{*}{$\begin{array}{c}0 \text { hour } \\
\begin{array}{c}\text { Phos- } \\
\text { phorus } \\
\text { mg./ } \\
100 \text { cc. }\end{array} \\
\text { Lipide }\end{array}$} & \multicolumn{7}{|c|}{24 hours } & \multicolumn{4}{|c|}{48 hours } \\
\hline \multirow{2}{*}{ Name, } & & & & $\begin{array}{l}\text { Phosf } \\
\text { mg./I }\end{array}$ & $\begin{array}{l}\text { horus } \\
00 \text { cc. }\end{array}$ & $\underset{r . r . u . /}{\text { Radioa }}$ & $\begin{array}{l}\text { tivityt } \\
00 \mathrm{cc} \text {. }\end{array}$ & $\begin{array}{r}\text { Spe } \\
\text { acti } \\
\times\end{array}$ & $\begin{array}{l}\text { ific } \\
\text { ty } \\
0\end{array}$ & $\begin{array}{c}\text { Relative } \\
\text { specific } \\
\text { activity } \\
\times 100\end{array}$ & $\begin{array}{l}\text { Phosp } \\
\text { mg./1 }\end{array}$ & $\begin{array}{l}\text { horus } \\
00 \text { cc. }\end{array}$ & $\begin{array}{c}\text { Radioa } \\
r . r . u . /\end{array}$ & $\begin{array}{l}\text { ivityt } \\
00 c \text {. }\end{array}$ \\
\hline & & & & Inorg. & Lipide & Inorg. & Lipide & Inorg. & Lipide & Lipide & Inorg. & Lipide & Inorg. & Lipide \\
\hline \multirow[t]{3}{*}{ O. A. } & 1\| & Choline & 11.70 & 2.87 & 11.16 & .635 & 1.785 & 22.1 & 16.0 & 72.5 & 3.18 & 10.25 & .635 & 1.740 \\
\hline & 2 & & 7.96 & 3.94 & 6.96 & 1.360 & .450 & 34.6 & 6.4 & 18.5 & 3.96 & 6.23 & .965 & .766 \\
\hline & $3 \|$ & Choline & 11.25 & 3.64 & 11.72 & .708 & .710 & 19.4 & 6.1 & 31.4 & 3.50 & 11.36 & .582 & 1.012 \\
\hline \multirow[t]{3}{*}{ N. H. H. 36 F } & 1II & Methionine & 11.84 & . & 11.10 & & 3.810 & & 34.3 & & & & & \\
\hline & 2 & & 9.01 & 3.05 & 6.41 & 1.510 & .533 & 49.6 & 8.3 & 16.9 & 3.54 & 7.60 & 1.350 & 1.270 \\
\hline & $3 \|$ & Methionine & 5.11 & 2.84 & 6.70 & .990 & .712 & 34.8 & 10.6 & 30.5 & 3.16 & 8.28 & .624 & 1.334 \\
\hline \multirow[t]{2}{*}{ N. R. T. $30 \mathrm{M}$} & $1 \|$ & Choline & 6.05 & 2.54 & 5.36 & .835 & .875 & 32.9 & 16.3 & 49.5 & 2.29 & 6.25 & .531 & 1.321 \\
\hline & $2 \|$ & Choline & 6.03 & 3.54 & 6.98 & 1.070 & .775 & 30.2 & 11.1 & 36.8 & 3.62 & 8.24 & .750 & 1.260 \\
\hline \multirow[t]{2}{*}{ H. F. E. $35 \mathrm{M}$} & 1II & Choline & 6.09 & 2.60 & 6.61 & .742 & 1.673 & 28.5 & 25.3 & 89.0 & 2.95 & 5.79 & .743 & 1.171 \\
\hline & $2 \|$ & Choline & 4.65 & 2.89 & 4.74 & .991 & .482 & 34.3 & 10.1 & 29.4 & 3.41 & 3.98 & .909 & .596 \\
\hline \multirow[t]{2}{*}{ J. H. $\quad 31 \mathrm{M}$} & $1 \| 4$ & Choline & 12.20 & 3.20 & 12.40 & .930 & 1.106 & 29.1 & 8.9 & 30.6 & 2.98 & 12.80 & .742 & 1.955 \\
\hline & $2 \|$ & Choline & 8.14 & 3.39 & 7.40 & .708 & .441 & 20.9 & 6.0 & 28.7 & 3.27 & 8.22 & .615 & .892 \\
\hline \multirow[t]{2}{*}{$\begin{array}{lll}\text { C. F. } & 52 & M\end{array}$} & 1II & Choline & 7.33 & 2.73 & 7.95 & .955 & 1.046 & 34.9 & 13.2 & 37.8 & 3.36 & 8.25 & .806 & 1.716 \\
\hline & $2 \|$ & Choline & 10.05 & 3.31 & 9.46 & .710 & .788 & 21.4 & 8.3 & 38.8 & 3.46 & 11.42 & .482 & 1.350 \\
\hline \multirow[t]{2}{*}{ B. S. } & 111 & Choline & 9.14 & 2.98 & 9.02 & 1.108 & 1.874 & 37.2 & 20.8 & 55.9 & 2.67 & 8.31 & .677 & 2.135 \\
\hline & $2 \|$ & Choline & 6.52 & 2.59 & 5.07 & .868 & .733 & 33.5 & 14.4 & 43.0 & 3.36 & 6.46 & .770 & 1.284 \\
\hline \multirow[t]{2}{*}{ R. W. $46 \mathrm{M}$} & 11 & Choline & 6.08 & 2.53 & 6.18 & .630 & .473 & 24.9 & 7.7 & 30.9 & 3.04 & 6.04 & .498 & .682 \\
\hline & 2\| & Choline & 6.78 & 3.19 & 7.52 & .608 & .556 & 19.1 & 7.4 & 38.8 & 2.86 & 8.90 & .404 & .972 \\
\hline
\end{tabular}

*t\$ll See footnotes to Table I. 
TABLE II-Continued

Phospholipide turnover before and after treatment with a single dose of a lipotroipc agent in patients with chronic hepatitis (Group 2)

\begin{tabular}{|c|c|c|c|c|c|c|c|c|c|c|c|c|c|c|}
\hline Patient & \multirow{3}{*}{$\begin{array}{l}\text { Time } \\
\text { of in- } \\
\text { jection } \\
\text { of Pa** }\end{array}$} & \multirow{3}{*}{$\begin{array}{l}\text { Material } \\
\text { given }\end{array}$} & \multicolumn{3}{|c|}{48 hours } & \multicolumn{7}{|c|}{ 72-96 hours } & \multirow{3}{*}{$\begin{array}{c}\begin{array}{c}\text { Specific } \\
\text { activity } \\
\text { of urine } \\
\text { inorganic } \\
\text { phos- } \\
\text { phorus }\end{array} \\
21-24 \text { hrs. }\end{array}$} & \multirow{3}{*}{$\begin{array}{c}\begin{array}{c}\text { Ratio of } \\
\text { specific } \\
\text { activities } \\
\text { of } \\
\text { urine P }\end{array} \\
\text { plasma P }\end{array}$} \\
\hline \multirow{2}{*}{ Name, a } & & & \multicolumn{2}{|c|}{$\begin{array}{c}\text { Specific } \\
\text { activity } \ddagger \\
\times 100\end{array}$} & \multirow{2}{*}{$\begin{array}{c}\begin{array}{c}\text { Relative } \\
\text { specific } \\
\text { activity } \$ \\
\times 100\end{array} \\
\text { Lipide }\end{array}$} & \multicolumn{2}{|c|}{$\begin{array}{l}\text { Phosphorus } \\
\text { mg./100 cc. }\end{array}$} & \multicolumn{2}{|c|}{$\begin{array}{c}\text { Radio- } \\
\text { activity } \dagger \\
\text { r.r.u./100 cc. }\end{array}$} & \multicolumn{2}{|c|}{$\begin{array}{l}\text { Specific } \\
\text { activity } \\
\times 100\end{array}$} & \multirow{2}{*}{$\begin{array}{c}\begin{array}{c}\text { Relative } \\
\text { 8pecific } \\
\text { activity } \$ \\
\times 100\end{array} \\
\text { Lipide }\end{array}$} & & \\
\hline & & & Inorg. & Lipide & & Inorg. & Lipide & Inorg. & Lipide & Inorg. & Lipide & & & \\
\hline \multirow[t]{3}{*}{ O. A. } & $1 \|$ & Choline & 20.0 & 17.0 & 85.0 & & & & & & & & 30.0 & 1.36 \\
\hline & 2 & & 24.4 & 12.3 & 50.3 & 3.84 & 8.92 & .458 & 1.356 & 11.9 & 15.1 & 126.8 & 47.8 & 1.38 \\
\hline & $3 \|$ & Choline & 16.6 & 8.9 & 53.6 & & & & & & & & 25.1 & 1.30 \\
\hline \multirow[t]{3}{*}{ N. H. H. 36 F } & $1 \|$ & Methionine & & & & & & & & & & & & \\
\hline & 2 & & 38.2 & 16.7 & 43.7 & 3.04 & 9.40 & .715 & 1.770 & 23.5 & 18.8 & 80.0 & 54.3 & 1.09 \\
\hline & $3 \|$ & Methionine & 19.7 & 16.1 & 81.7 & 3.11 & 9.68 & .468 & 1.700 & 15.0 & 17.5 & 116.6 & & \\
\hline \multirow[t]{2}{*}{ N. R. T. $30 \mathrm{M}$} & $1 \|$ & Choline & 23.2 & 21.2 & 91.4 & 2.87 & 6.60 & .455 & 1.510 & 15.9 & 22.8 & 143.5 & 37.5 & 1.14 \\
\hline & $2 \|$ & Choline & 20.7 & 15.3 & 73.9 & 3.35 & 7.88 & .440 & 1.187 & 13.1 & 15.1 & 115.3 & 26.2 & 0.86 \\
\hline \multirow[t]{2}{*}{ H. F. E. $35 \mathrm{M}$} & $1 \|$ & Choline & 25.2 & 20.2 & 80.0 & 2.74 & 7.57 & .472 & 1.427 & 17.2 & 18.8 & 109.0 & 40.3 & 1.41 \\
\hline & $2 \|$ & Choline & 26.6 & 14.9 & 55.9 & 4.00 & 4.63 & .566 & .729 & 14.1 & 15.7 & 111.3 & 39.9 & 1.16 \\
\hline \multirow[t]{2}{*}{ J. H. } & $1 \| \mathbb{T}$ & Choline & 24.9 & 15.2 & 61.1 & 2.86 & 14.00 & .534 & 2.250 & 18.7 & 16.1 & 86.1 & 38.8 & 1.33 \\
\hline & $2 \|$ & Choline & 18.8 & 10.8 & 57.5 & & & & & & & & 31.3 & 1.48 \\
\hline \multirow[t]{2}{*}{ C. F. } & $1 \|$ & Choline & 23.9 & 20.8 & 87.1 & & & & & & & & 55.3 & 1.58 \\
\hline & $2 \|$ & Choline & 13.9 & 11.8 & 84.9 & & & & & & & & 25.4 & 1.18 \\
\hline \multirow[t]{2}{*}{ B. S. } & $1 \|$ & Choline & 25.3 & 25.7 & 101.5 & 2.62 & 8.17 & .566 & 2.203 & 21.6 & 26.9 & 124.5 & 46.3 & 1.24 \\
\hline & $2 \|$ & Choline & 22.9 & 19.9 & 86.9 & & & & & & & & & \\
\hline \multirow[t]{2}{*}{ R. W. $46 \mathrm{M}$} & $1 \|$ & Choline & 16.4 & 11.3 & 68.9 & & & & & & & & & \\
\hline & $2 \|$ & Choline & 14.2 & 10.9 & 77.0 & & & & & & & & 28.0 & 1.47 \\
\hline
\end{tabular}

I Received some methionine before the choline was administered.

Group 2: Phospholipide turnover studied before and during treatment with a large "test dose" of methionine or choline (Table I.I and

Figure 2)

Eight consecutive patients with portal cirrhosis (Group 2) who received an initial large "test dose" of a lipotropic agent before treatment and after two to four months of a therapeutic regimen which included the daily administration of $3 \mathrm{Gm}$. of methionine. Before treatment the "test dose" increased the rate of phospholipide turnover.

Eight patients who were studied before and after treatment received a large dose of a lipotropic substance with both injections of radioactive phosphorus. Seven received choline and one received methionine. There were six men and two woman in this group. The ages ranged from 30 to 52 , with an average age of 39 . All had enlarged livers; five were jaundiced, and five had ascites. Biopsies were done on six patients. Six gave a history of alcoholism.

\section{Group 3: Phospholipide turnover studied before} treatment for the effect of a large "test dose" of methionine or choline (Table III)

The phospholipide turnover after a large "test dose" of lipotropic substance was studied before treatment in four patients in whom no follow-up determinations have yet been obtained. This group consisted of three men and one woman, ranging in age from 28 to 58 years, with an average age of 50 years. Three patients were jaundiced; two had ascites, and three had enlargement of the liver. There was a history of alcoholism in three. Biopsies were done in all four cases.

\section{RESULTS}

\section{Group 1: Phospholipide turnover measured before and after treatment}

\section{Lipide phosphorus}

It will be seen from the data (Table I) that the level of lipide phosphorus in some of these individuals was measured several times over a period of four months and found to be relatively constant. The levels before and after a two-month period of treatment failed to show any demonstrable difference. Of the three patients to whom a large single dose of choline chloride $(10 \mathrm{Gm}$.) was given after a two-month period of treatment, a rise in 
the phospholipide phosphorus was observed in only one patient (E.S.).

The radioactivity and specific activity values before and after a two-month period of treatment were approximately the same. In only one patient (A.K.O.) were the values for radioactivity and specific activity increased. In the three patients (W.R.S., E.S., and R.N.O.) who received a single large dose of choline after two to four months of treatment no stimulating action was demonstrated. Indeed, the radioactivity and specific activity values of the lipides in each of these three individuals were approximately the same after the administration of a single large dose of choline as before any "test dose" or treatment was given.

\section{Inorganic phosphorus}

In most of these patients the specific activities of the inorganic phosphate were determined before and after treatment. Except in one case, the values obtained before and after treatment, or fol- lowing the administration of a single large dose of choline, were similar.

\section{Relative specific activity of lipide phosphorus}

In each of four patients the relative specific activity was found to be practically unchanged after two months or more of treatment. In three of these patients a single large dose of choline had no effect, but in the fourth patient (R.N.O.), while no change was apparent in the specific activity of the lipide phosphorus, the relative specific activity was greater after the administration of a single large dose of choline. This increase was due to the lowering of the specific activity of the inorganic phosphorus.

\section{Groups 2 and 3: Phospholipide turnover studied before and during treatment with large "test dose" of methionine or choline}

\section{Lipide phosphorus}

The level of lipide phosphorus in most of the 12 patients in these two groups remained sub-

TABLE III

Phospholipide turnover before treatment with a single dose of a lipotropic agent in patients with chronic hepatitis (Group 3)

\begin{tabular}{|c|c|c|c|c|c|c|c|c|c|c|c|c|c|c|}
\hline \multirow{3}{*}{ Name, age, sex } & \multirow{3}{*}{$\begin{array}{l}\text { Time } \\
\text { of in- } \\
\text { jection } \\
\text { of Pos }\end{array}$} & \multirow{3}{*}{$\begin{array}{c}\text { Material } \\
\text { given }\end{array}$} & \multirow{3}{*}{$\begin{array}{c}0 \text { hour } \\
\begin{array}{c}\text { Phos- } \\
\text { phorus } \\
\text { mg./ } \\
100 \text { cc. }\end{array} \\
\text { Lipide }\end{array}$} & \multicolumn{7}{|c|}{24 hours } & \multicolumn{4}{|c|}{48 hours } \\
\hline & & & & \multicolumn{2}{|c|}{$\begin{array}{l}\text { Phosphorus } \\
\mathrm{mg} . / 100 \mathrm{cc} \text {. }\end{array}$} & \multicolumn{2}{|c|}{$\begin{array}{c}\text { Radioactivity } \dagger \\
r . r . u . / 100 \text { cc. }\end{array}$} & \multicolumn{2}{|c|}{$\begin{array}{l}\text { Specific } \\
\text { activity } \\
\times 100\end{array}$} & \multirow{2}{*}{$\begin{array}{c}\begin{array}{c}\text { Relative } \\
\text { specific } \\
\text { activity } \\
\times 100\end{array} \\
\text { Lipide }\end{array}$} & \multicolumn{2}{|c|}{$\begin{array}{l}\text { Phosphorus } \\
m g . / 100 ~ c c .\end{array}$} & \multicolumn{2}{|c|}{$\begin{array}{c}\text { Radioactivity† } \\
\text { r.r.u./100 cc. }\end{array}$} \\
\hline & & & & Inorg. & Lipide & Inorg. & Lipide & Inorg. & Lipide & & Inorg. & Lipide & Inorg. & Lipide \\
\hline J. R. J. 58 M & 1 & Choline & 6.91 & & 8.22 & & 1.365 & & 16.6 & & & 8.14 & & 1.713 \\
\hline $28 \mathrm{M}$ & 1 & Methionine & 10.18 & 1.38 & 6.88 & .324 & 1.034 & 23.5 & 15.1 & 64.3 & 2.50 & 12.63 & .510 & 2.740 \\
\hline $53 \mathrm{~F}$ & 1 & Choline & 11.95 & 2.97 & 11.60 & .852 & .996 & 28.7 & 8.6 & 29.9 & 3.29 & 13.14 & .724 & 1.950 \\
\hline $\begin{array}{lll}\text { R. T. } & 58 & M\end{array}$ & 1 & Methionine & 4.46 & 2.78 & 6.12 & .717 & .980 & 25.8 & 16.0 & 62.0 & 2.87 & 6.36 & .796 & 1.988 \\
\hline
\end{tabular}

TABLE III-Continued

Phospholipide turnover before treatment with a single dose of a lipotropic agent in patients with chronic hepatitis (Group 3)

\begin{tabular}{|c|c|c|c|c|c|c|c|c|c|c|c|c|c|c|}
\hline \multirow{3}{*}{$\begin{array}{c}\text { Patient } \\
\text { Name, age, sex }\end{array}$} & \multirow{3}{*}{$\begin{array}{l}\text { Time } \\
\text { of in- } \\
\text { jection } \\
\text { of Pat* }\end{array}$} & \multirow{3}{*}{$\underset{\text { given }}{\text { Material }}$} & \multicolumn{3}{|c|}{48 hours } & \multicolumn{7}{|c|}{ 72-96 hours } & \multirow{3}{*}{$\begin{array}{c}\begin{array}{c}\text { Specific } \\
\text { activity } \\
\text { of urine } \\
\text { inorganic } \\
\text { phos- } \\
\text { phorus }\end{array} \\
21-24 \text { hrs. }\end{array}$} & \multirow{3}{*}{$\begin{array}{c}\begin{array}{c}\text { Ratio of } \\
\text { specific } \\
\text { activities } \\
\text { of } \\
\text { urine P }\end{array} \\
\text { plasma P } \\
21-24 \text { hrs. }\end{array}$} \\
\hline & & & \multicolumn{2}{|c|}{$\begin{array}{c}\text { Specific } \\
\text { activity } \ddagger \\
\times 100\end{array}$} & \multirow{2}{*}{$\begin{array}{c}\begin{array}{c}\text { Relative } \\
\text { specific } \\
\text { activity } \\
\times 100\end{array} \\
\text { Lipide }\end{array}$} & \multicolumn{2}{|c|}{$\begin{array}{l}\text { Phosphorus } \\
\text { mg./100 cc. }\end{array}$} & \multicolumn{2}{|c|}{$\underset{\text { r.r.u./100 cc. }}{\text { Radio- }}$} & \multicolumn{2}{|c|}{$\begin{array}{l}\text { Specific } \\
\text { activity } \ddagger \\
\times 100\end{array}$} & \multirow{2}{*}{$\begin{array}{c}\begin{array}{c}\text { Relative } \\
\text { specific } \\
\text { activity } \$ \\
\times 100\end{array} \\
\text { Lipide }\end{array}$} & & \\
\hline & & & Inorg. & Lipide & & Inorg. & Lipide & Inorg. & Lipide & Inorg. & Lipide & & & \\
\hline J. R. J. 58 M & 1 & Choline & & 21.0 & & 2.42 & 7.48 & .434 & 1.730 & 17.9 & 23.1 & 129.0 & & \\
\hline $28 M$ & 1 & Methionine & 20.4 & 21.7 & 106.5 & 3.40 & 13.07 & .590 & 2.757 & 17.4 & 21.1 & 121.3 & & \\
\hline 53 F & 1 & Choline & 22.2 & 14.9 & 67.3 & 2.39 & 12.45 & .374 & 2.335 & 15.6 & 18.7 & 120.0 & 22.1 & 0.77 \\
\hline $58 \mathrm{M}$ & 1 & Methionine & 27.7 & 31.3 & 113.0 & & & & & & & & & \\
\hline
\end{tabular}

* †t\& See footnotes to Table I. 
stantially unchanged 24 hours after the administration of a single large "test dose" of choline or methionine. The eight patients in Group 2 were restudied after a two-month period of treatment, again receiving a single large dose of choline or methionine; approximately the same lipide phosphorus levels were found.

In seven of the eight patients in Group 2, the radioactivity and specific activity of the plasma lipides following a "test dose" of methionine or choline were considerably higher before treatment than the corresponding values found in the same patient after an interval of treatment even when a large "test dose" of lipotropic substance was again given.

Table III shows the data obtained in four untreated patients who received a single large "test dose" of a lipotropic agent, but in whom repeated determinations could not be made (Group 3). Because of the variability of the phospholipide turnover, even in normal individuals (9), no definite conclusions can be drawn from these data. However, in three of these four patients the specific activities of the lipide phosphorus at the 24th hour were in the same range as those obtained after the administration of an initial large dose of choline to the patients in Group 2.

\section{Inorganic phosphorus}

In each of the eight patients in Group 2, the radioactivity and specific activity values of this fraction following a "test dose" of a lipotropic agent were the same before and after prolonged therapy with methionine.

\section{Relative specific activity of lipide phosphorus}

In four out of the eight patients in Group 2, the relative specific activity values of plasma phospholipides following the administration of a "test dose" of methionine or choline were considerably higher before treatment than the corresponding values found in the same patient after a period of treatment. In one patient (N.H.H.) the inorganic fraction was not analyzed and the relative specific activity could not be calculated. In patient R.W. both the specific activity and the relative specific activity remained unchanged after treatment. In the remaining two patients (J.H. and C.F.), although there was a definite decrease in the specific activity values after treatment, this decrease becomes less significant if the values are expressed as relative specific activity. In the case of J.H., the small degree of stimulation by the initial dose of choline may be partly explained by the fact that the patient had received some methionine previously before the initial "test dose" of choline was administered.

\section{Urine phosphorus (Tables I-III)}

In the urine collected during a three-hour period (21-24 hours after the injection of radiophosphorus), the specific activity of the phosphate varied widely between different individuals. However, in nine patients in whom repeated determinations were made (Tables I and II) the ratio of the specific activity of the urine to the plasma phosphate was rather constant over the period of study. In almost all cases this ratio was greater than 1 . It appears from our data that the specific activity of the plasma inorganic phosphorus does not reach a plateau at the 24th hour, since the values at the 48th hour are definitely lower. Accordingly, the specific activity of the inorganic phosphorus in the urine collected for a three-hour period preceding the 24th hour should correspond to the average specific activity of the plasma phosphate during this period. The ratio between the urine phosphate and the plasma phosphate should vary proportionately to the slope of the descending curve of the inorganic phosphate, unless there is some impairment in the renal excretion of phosphate. The finding of a ratio less than 1 in three normal persons (10) and in two of the present series is more difficult to explain. Similar observations, however, have been made in animals during the first few hours after the introduction of radioactive phosphorus. Govaerts suggests that the finding may be due to the presence in plasma of a phosphorus-containing fraction which is only slowly metabolized, but which is included in the value obtained with the common methods for determining inorganic phosphorus (11).

\section{DISCUSSION}

The concepts regarding the etiology of hepatic cirrhosis have undergone considerable change in the past decade, and the prognosis for such patients - even those having jaundice, ascites, and laboratory evidence of markedly impaired liver function 
-has greatly improved. Indeed, it is felt by some investigators that in less advanced cases of cirrhosis the liver may be almost completely reverted to normal $(12,13)$. When pathologic changes have progressed to marked fibrosis, it is difficult to believe that any resolution of fibrous tissue itself occurs. On the other hand, it does appear that many patients have considerable associated fatty infiltration, which in itself produces profound intracellular metabolic disturbances and probably stimulates fibroblastic activity. It is in such patients that one might expect an excellent response to treatment, with satisfactory cellular repair, regeneration, and restoration of physiologic cellular compensation.

Studies in animals and human beings have definitely proven the advantage of a diet high in protein for the treatment of cirrhosis. It seems at present that more than one effect is obtained from the protein, which acts as a precursor for lipotropic substances and also specifically causes regeneration of liver parenchyma. In addition a detoxifying effect has also been claimed-as, for example, in instances of carbon tetrachloride poisoning (14).

It has been the practice of many clinicians to supplement the high-protein diet with substances known to have a lipotropic effect in animalsnamely, choline and methionine. The clinical efficacy of these substances in human patients, however, remains to be proved.

In experimental animals with fatty livers induced by diet, it has been shown by using radioactive phosphorus as an indicator that the administration of choline (3) or methionine (4) increases the phospholipide synthesis in the liver. Since the plasma phospholipides are derived almost entirely from the liver (15), it would appear than an increase in the turnover of plasma phospholipides would indicate an increased synthesis by the liver. Indeed, in dogs maintained on a diet low in protein and high in fat, an increase in the plasma phospholipide turnover has been demonstrated following the administration of choline (16).

\section{Group 1: Phospholipide turnover studied before and after treatment}

The concentration of radiophosphorus in the plasma lipides of cirrhotic patients was determined before and after a two-month period of treatment and compared with those values found two months later after a second injection of radiophosphorus. Because of the wide variations between individuals, both normal and cirrhotic, it was necessary to use each patient as his own control $(9,10) .^{2}$

In most of our patients the specific activity of the inorganic phosphorus and the radioactivity and specific activity of the lipides remained rather constant in the same individual, even after several months of treatment with methionine $(3 \mathrm{Gm}$. per day). Only in patient A.K.O. was there an increase in the radioactivity and specific activity of the lipide phosphorus following treatment. A similar increase was found in patient E.S. after the administration of an additional large dose of choline; however, the significance of this finding is questionable, since it probably was due to a marked increase in the specific activity of the inorganic phosphate. Of two other patients in whom a large dose of choline was given after four months of treatment, only one (R.N.O.) showed an increase in the relative specific activity following treatment. All other values were unchanged.

In general it may be stated that two or more months of treatment, including $3 \mathrm{Gm}$. of methionine per day, produced no consistent change in the rate of phospholipide turnover in the plasma, even when the patients showed considerable clinical and laboratory evidence of improvement, and that the transfer of liver phospholipide to plasma occurred at a relatively constant rate for the individual, even in the presence of severe liver damage.

\section{Groups 2 and 3: Phospholipide turnover studied before and during the regular treatment re- gime after an initial large "test dose" of methionine or choline}

In experimental animals with fatty infiltration of the liver induced by diet, single massive doses of choline or methionine have a marked stimulatory effect on the conversion of inorganic phosphate to plasma phospholipides. In animals on diets adequate in choline, or its precursors, the effect is not as apparent (4). It was felt that any stimulating action of these lipotropic substances in human patients would be detectable only by the

\footnotetext{
2 This same variability had been noted by Balfour in a study which included nine normal persons and 21 patients with various diseases, including three untreated cases of cirrhosis (17).
} 
administration of a large dose of choline or methionine before treatment, when the disorder was acute. Accordingly, a total of 12 patients who had had no previous treatment were studied following the administration of a large single "test dose" of choline or methionine. After the patients were treated for two months with methionine and a high-protein diet, the phospholipide turnover in eight patients was studied again after the administration of a second "test dose" of lipotropic material. It will be seen from Table II that, for seven out of these eight patients, the initial radioactivity and specific activity values of the plasma phospholipides were considerably higher than the corresponding values obtained following treatment.

It would seem, therefore, that in these seven patients the initial large dose of methionine or choline actually produced a marked increase in phospholipide turnover. Such an increase could no longer be demonstrated following prolonged therapy with methionine or choline.

It has been generally assumed that the development of fatty livers in experimental animals is dependent upon a decrease in the rate at which choline-containing phospholipides are turned over in the body. The effect of a choline lack is possibly to retard the formation of choline-containing phospholipides; conversely, the administration of choline would correct the fatty infiltration by stimulating phospholipide turnover. However, in experimental animals the stimulating action of a large dose of choline is evident only when the supply of choline or its precursors is insufficient.

In our study the response which some patients showed to the administration of a single large initial dose of choline or methionine might be interpreted to indicate a relative deficiency in lipotropic agents. Therefore, one would not anticipate a similar response after an interval of adequate treatment.

In view of the relationship between the liver and the plasma phospholipides, the demonstrable increase in the phospholipide turnover and in the formation of new phospholipides produced by large initial doses of choline or methionine would appear to justify the use of these lipotropic agents in the treatment of certain forms of liver disease.

\section{CONCLUSION}

Studies of experimentally induced liver disease in animals have indicated that fatty infiltration often occurs early, and may represent an intermediate phase which, if untreated, can progress to extensive fibrosis, producing the clinical picture of portal cirrhosis. In such instances, lipotropic agents often appear to exert a beneficial effect, which has been attributed to a stimulatory action on the synthesis and turnover of phospholipides.

Our present study and previous experiments have indicated that the phospholipide synthesis as measured in the plasma of untreated cirrhotic patients after an injection of radiophosphorus, falls within the lower limits of the range found for normal persons. Following a two-month interval of therapy no increase in the rate of synthesis can be detected, even when clinical improvement is pronounced and is associated with improvement in the conventional tests of liver function.

When eight untreated cirrhotic patients (all having large livers) were given an initial $10 \mathrm{Gm}$. dose of methionine or choline chloride, a significant increase in the plasma phospholipide synthesis was demonstrable in seven of the patients. This effect could not be demonstrated in the same patients after an interval of treatment.

Since the administration of a single large dose of choline to a normal person will not alter the phospholipide synthesis (10), it would appear that the stimulating effect is evident only when the supply of choline or its precursors has been insufficient. Accordingly, the initial response of cirrhotic patients to a "test dose' of a lipotropic substance may be indicative of a relative insufficiency of choline or choline precursors in such persons.

We wish to acknowledge the helpful suggestions and constructive criticism of Dr. Camillo Artom and the technical assistance of Dr. Benjamin Vatz and Mr. Jesse C. Trott, Jr.

Part of the choline in this study was in the form of tablets of choline dihydrogen citrate, and was supplied by the Department of Clinical Investigation of Parke, Davis and Company, Detroit, Michigan. The remainder was given as choline chloride.

\section{BIBLIOGRAPHY}

1. Best, C. H., and Ridout, J. H., Choline as a dietary factor, in: Annual Review of Biochemistry. Stanford University, Calif., Annual Reviews, Inc., vol. 8, pp. 349, 1939. 
2a. Best, C. H., and Huntsman, M. E., Effects of components of lecithine upon deposition of fat in liver. J. Physiol., 1932, 75, 405.

b. Channon, H. J., Manifold, M. C., and Platt, A. P., Action of sulfur-containing amino-acids and proteins on liver fat deposition. Biochem. J., 1940, 34, 866.

3. Zilversmit, D. B., Entenman, C., and Chaikoff, I. L., The measurement of turnover of the various phospholipides in liver and plasma of the dog and its application to the mechanisms of action of choline. J. Biol. Chem., 1948, 176, 193.

4. Artom, C., and Cornatzer, W. E., The action of choline and fat on lipide phosphorylation in the liver. J. Biol. Chem., 1947, 177, 779.

5. Perlman, I., Stillman, N., and Chaikoff, I. L., Radioactive phosphorus as an indicator of phospholipid metabolism. XI. The influence of methionine, cystine, and cysteine upon phospholipide turnover in the liver. J. Biol. Chem., 1940, 133, 651.

6. Patek, A. J., Evaluation of dietary factors in treatment of Laennec's cirrhosis of liver. J. Mt. Sinai Hosp., 1947, 14, 1.

7. Beams, A. J., The treatment of cirrhosis of the liver with choline and cystine. J. A. M. A., 1946, 130, 190.

8. Volwiler, W., Jones, C. M., and Mallory, T. B., Criteria for the measurement of results of treatment in fatty cirrhosis. Gastroenterology, 1948, 11, 164.
9. Cayer, D., and Cornatzer, W. E., Radioactive phosphorus as an indicator of the rate of phospholipide formation in patients with liver disease. Gastroenterology, 1950, 14, 1.

10. Cornatzer, W. E., and Cayer, D., The effects of lipotropic factors on phospholipide turnover in the plasma of normal persons as indicated by radioactive phosphorus. J. Clin. Invest., 1950, 29, 534.

11. Govaerts, J., Urinary excretion of phosphate with ${ }_{15}^{22} \mathrm{P}$ as indicator. Nature, 1947, 160, 53.

12. Morrison, L. M., The response of cirrhosis of the liver to an intensive combined therapy. Ann. Int. Med., 1946, 24, 465.

13. Steinberg, B., and Martin, R., Absorption of scar tissue in experimental nodular cirrhosis of the liver. Arch. Path., 1946, 41, 1.

14. Beattie, J., and Marshall, J., Methionine in the treatment of liver damage. Nature, 1944, 153, 525.

15. Fishler, M. C., Entenman, C., Montgomery, M. L., and Chaikoff, I. L., The formation of phospholipid by the hepatectomized $\operatorname{dog}$ as measured with radioactive phosphorus. J. Biol. Chem., 1943, 150, 47.

16. Friedlander, H. D., Chaikoff, I. L., and Entenman, C., The effect of ingested choline on the turnover of plasma phospholipids. J. Biol. Chem., 1945, 158, 231.

17. Balfour, W. M., Human plasma phospholipide formation: a study made with the aid of radiophosphorus. Gastroenterology, 1947, 9, 686. 